\title{
From Mentoring to Career Satisfaction: The Roles of Distributive Justice and Organizational Commitment
}

\author{
İzlem Gözükara ${ }^{1}$ \\ ${ }^{1}$ Department of Business Administration, Istanbul Arel University, İstanbul, Turkey \\ Correspondence: İzlem Gözükara, Istanbul Arel University, İstanbul, Turkey.
}

Received: January 26, 2017

Accepted: February 10, 2017

Online Published: February 18, 2017

doi:10.5430/jms.v8n1p61

URL: http://dx.doi.org/10.5430/jms.v8n1p61

\begin{abstract}
A mentor-mentee relationship is a productive partnership on both sides. Mentoring has been repeatedly shown to positively influence several work-related outcomes in an organization. Therefore, the present study explored how mentoring, distributive justice, organizational commitment and career satisfaction are related to each other in order to reveal the mentoring effects both at individual and organizational levels. The study included a sample of 280 participants. SPSS 22.0 and AMOS 22.00 software programs were used to perform the statistical analyses of the study data. The results revealed that mentor role and distributional justice have positive effects on organizational commitment, while organizational commitment positively affects career satisfaction. There was also a positive covariance between mentor role and distributive justice. The findings are discussed from the perspective of both management literature and organizational implications.
\end{abstract}

Keywords: mentor role, mentoring, distributive justice, organizational commitment, career satisfaction

\section{Introduction}

Mentoring is both a human resources practice and an individual strategy toward career success (e.g. Atkinson, 2002; O'Reilley, 2001). Mentoring refers to a process during which the experienced employees of an organization help newcomers complete their individual and organizational development by mentoring them (Özkalp et al., 2006). Having advanced experience and knowledge, mentors are individuals who are dedicated to offer their mentees support and flexibility (Kram, 1985). Mentors typically provide two main functions; career development functions help the mentee advance within the organization, and psychosocial function supports individual and professional development of the mentee (Kram, 1985).

There has been a considerable amount of research on the antecedents and outcomes of mentoring. For instance, mentoring has been shown to highly relate to positive outcomes for employees (Allen et al., 1997) such as organizational commitment (Joiner et al., 2004). Higgins and Kram (2001) have identified a positive link between mentoring and commitment. According to Fine and Pullins (1998), mentoring serves as a professional tool for development, which is likely to foster commitment to the organization and satisfaction with career.

Since mentoring is an effective strategy for the entire organization, the perceptions of employees about its fairness may influence the desired outcomes. Fairness is an important construct especially for employees. Based on the Equity Theory (Adams, 1965), distributive justice is a type of organizational justice, reflecting the extent to which employees perceive inputs and outputs as fair and just. Justice within an organization has been found to be positively linked with organizational commitment (e.g. Chang and Dubinsky, 2005). A positive relationship has also been demonstrated between mentoring and employees' justice perceptions (Scandura, 1997).

In light of the above theoretical background, the purpose of the present study is to explore the inter-relationships among mentoring, distributive justice, organizational commitment and career success. More specifically, the present study tries to reveal how a mentor can influence employees' perceptions of fairness and commitment as well as how career satisfaction is affected by these constructs.

\section{Mentoring}

Mentoring, which was first introduced by Kram in 1985, generally refers to the work relationship between a mentor, who has more experience and qualification, and a mentee, who has less experience for career and personal 
development (Kram, 1985). The common opinion is that mentoring helps maintaining long-term relationships between an organization and its members (Ragins \& Kram, 2007).

According to Bozeman and Feener (2007), mentoring is "a process for the informal transmission of knowledge, social capital, and psychosocial support perceived by the recipient as relevant to work, career, or professional development" (p. 731). Accordingly, the informal communication during mentoring is often a face-to-face communication "between someone perceived to have greater relevant knowledge, wisdom, or experience (the mentor) and a person who is perceived to have less (the protégé)" (p. 731).

Although sometimes used as a synonym of coaching or advising, mentoring is a different concept with a focus on long-term relationships, long-term goals, and personal and career development. Rather than a unidirectional instruction like teaching, mentoring involves a bilateral partnership based on learning between a mentor and a mentee. Such partnership helps mentees realize their own potential and development, and achieve their individual goals. Mentoring involves two approaches; formal communication that is called official mentoring supplied by the organization or informal communication that is called unofficial mentoring not designated by the organization (Eby et al., 2000).

Mentoring has been investigated for over three decades in in different professions, disciplines and institutions such as educational institutions, public organizationsand private organizations. The majority of research on mentoring has focused on how to classify the functions or benefits of mentoring process. Though no consensus has been reached on the components of mentoring, it is widely recognized that mentoring has a multidimensional structure (Haggard et al., 2011; Viator, 2001). Some researchers (Kram, 1985; Reid et al., 2008) defined mentoring with two functions; career development and psychosocial support. Other researchers (Scandura, 1992; Weinberg \& Lankau, 2011) suggested role modeling as a third function besides career development and psychosocial support. Career functions involve coaching, sponsorship, exposure and visibility, protection and challenging assignments. Psychosocial functions, in turn, involve acceptance and confirmation, role modeling, friendship and counseling. The difference between mentoring and sponsoring is that psychosocial guidance is provided by the mentors in addition to guidance on career (Thomas, 1993).

Mentoring has become a popular subject among researchers, especially regarding the favorable outcomes of mentoring programs. Such outcomes have been examined in relation to job satisfaction (e.g. Ensher et al., 2001), learning (e.g. Lankau \& Scandura, 2002), turnover (e.g. Beckert \& Walsh, 1991), career development (e.g. Haggard et al., 2011; Scandura, 1992) and organizational commitment (e.g. Ragins et al., 2000). Mentoring can also produce varying effects based on the mentor and mentee (e.g. Darling et al., 2006), interaction quality of mentoring (e.g. Ragins et al., 2000), mentoring program (e.g. Ragins \& Verbos, 2007), qualification of the mentor (e.g. Haggard et al., 2011) and age of the mentor and mentee (e.g. Murphy, 2012).

\section{Distributive Justice}

As social systems, organizations place great importance on human resources for achieving productivity and effectiveness. Distributive justice refers to employees' perception of fair treatment within an organization, which reflects on employees' reactions and behaviors (Fernandes \& Raed, 2006). More specifically, distributive justice is related to the employees' opinion about fair treatment regarding their job and their work behaviors are shaped by that opinion (Moorman, 1991).

Distributive justice is the fair allocation of resources, workloads and rewards within an organization. It is about the fairness perception regarding resource allocation among people (Greenberg \& Baron, 2003). According to Cropanzano et.al. (2001), there are three principles leading to distributive justice: The first one is equality and it refers to equal treatment in benefits and burdens; the second principle is equity referring to input-based distribution of resources, and the last principle is need which refers to equal outcomes.

The extent to which employees perceive their organization as just and fair is directly associated with their work attitudes. An organization that fairly distributes rewards directs employees to develop behaviors more preferable by the organization (Ashar \& Shahbaz, 2013). For instance, Loi et al. (2006) suggested that distributive justice is likely to have a considerable role for employees in assessing their organization. Therefore, justice at an organization is an important concept linked with organizational success and effectiveness. Employees are likely to develop a greater attachment to their organization when they think they are treated in the same manner (Lee et al. 2007). Additionally, distributive justice has been found to positively affect employees' organizational commitment (Akanbi \& Ofoegbu, 
2013). Fair actions of an organization in resource and reward distribution, thereby, would result in employees who are attached and committed to their organization.

\section{Organizational Commitment}

Organizational commitment is of significance due to managerial concerns in organizations. It simply represents the extent to which employees develop a sense of loyalty to their organization and thereby adopt organizational goals (Lambert et al., 2007). Organizational commitment indicates an employee's emotional bond to organizational goals, values and missions (Jaskyte \& Lee, 2009). Employees who develop commitment to their organization are likely to provide greater contribution to that organization.

Organizational commitment has been identified as an outcome in almost all reviews on organizational justice. Employees' perception of justice and fairness drives them to develop a sense of belonging, which is an important aspect of organizational commitment. According to Chang and Dubinsky (2005), all types of organizational justice (distributive, procedural and interactional) have a positive relationship with organizational commitment. The effect of distributive justice on the level of organizational commitment was established in several studies (e.g. Aryee et al., 2002; Ramamoorthy \& Flood, 2004). For instance, the study by Lambert et al. (2007) indicates that both procedural and distributive justice have significant influence on organizational commitment of employees. The meta-analysis by Colquitt et al. (2011) also revealed that procedural and distributive justice significantly predicts organizational commitment.

The literature suggests that organizational commitment is also enhanced by mentoring (McManus \& Russell, 1997). Supervisor mentoring is likely to enhance employees' commitment to their organization. The positive influence of mentoring on organizational commitment has been explained by two theoretical reasons. First, mentoring stimulates affective commitment (Allen \& Meyer, 1990) and thereby, mentees' need for belonging and affection are met due to the perception of considerate treatment, which results in a higher level of attachment (Allen \& Meyer, 1990). Second, the mentees' satisfaction with the mentoring of senior management is likely to drive them to perceive the organization as more attractive, leading to enhanced levels of commitment (Orpen, 1997). In this regard, the study by Colarealli and Bishop (1990) concluded that career and psychosocial functions of mentoring have positive influence on organizational commitment.

\section{Career Satisfaction}

Career satisfaction refers to an employee's satisfaction or dissatisfaction about her/his career (Lounsbury et al., 2008). It involves a subjective assessment regarding the choice and development of a profession (Hofmans et al., 2000). Career satisfaction is broader than satisfaction just with the job; it encompasses both internal and external aspects of the profession (Judge et al., 1995). As stated by Judge and Kammeyer-Mueller (2007), job satisfaction often involves the instantaneous affective reactions of employees to their work; however, career satisfaction reflects a whole evaluation of the profession including the past and the future.

Career satisfaction is considered an important factor due to its relation to career success, specifically subjective career success that refers to one's emotional and psychological assessment of her/his accomplishments related to career (Siebert \& Kraimer, 2001). Understanding of the factors with influence on the subjective assessment of an individual is of significance. In this regard, Crant (2000) suggests that allowing employees to participate in career management actions may result in greater satisfaction with the career. Park (2010), in turn, suggests that the meaning of the job for the individual is among such factors because job may be perceived by one as an effort to maintain one's living but also eligible for building a career and providing favorable contributions to the world. Accordingly, the presence or absence of support on career management would be valuable for an employee. In this sense, Allen et al. (2004) found that employees with a mentor achieved better career outcomes compared to those with no mentor. Furthermore, the researchers determined that both functions of mentoring were in a positive relationship with career outcomes. In a similar vein, Scandura (1997) established that the psychosocial mentoring function positively affects employees' career expectations, satisfaction and commitment, which indicates that mentor support enables employees to overcome the challenges of career management as well as develop positive attitudes toward the work environment.

Career satisfaction is also related to several work-related outcomes such as commitment (Carson et al., 1994). Employees are likely to be satisfied with their career when their aims and needs are fulfilled (Joo \& Ready, 2012). Career satisfaction and organizational commitment are both emotional states that possibly result from employees' 
affective reactions to an organization. It is likely for employees to have greater levels of satisfaction when they feel committed to their organization.

Based on the above background, the present study developed the following hypotheses:

H1: Mentoring has a positive relationship with distributive justice.

H2: Mentoring has a positive relationship with organizational commitment.

H3: Distributive justice has a positive relationship with organizational commitment.

H4: Organizational commitment has a positive relationship with career satisfaction.

\section{Methodology}

\subsection{Research Goal}

The present study aims to determine the inter-relationship among mentoring, distributive justice, organizational commitment and career satisfaction. In this regard, the model created assumed that mentor role has a positive relationship with distributive justice and organizational commitment, while organizational commitment positively influences career satisfaction.

\subsection{Participants and Procedure}

For study purposes, the study questionnaire was distributed to 300 participants. Due to a large body of missing parts, questionnaires of 20 participants were ignored, and all study analyses were conducted with 280 participants. Questionnaire collection was completed over a period of 10 weeks.

\subsection{Measures}

The study questionnaire consisted of two parts. The first one was about demographics, which included gender, age, marital status, education and work details such as sector, position, seniority. The second part covered the questions to measure mentoring, distributive justice, organizational commitment and career satisfaction.

Mentoring was measured using the Mentor Role Instrument (MRI) developed by Ragins and McFarlin (1980). MRI is a scale with 33 items and 2 mentoring (career and psychosocial) functions that include 11 roles. These roles are sponsor $(\alpha=0.81)$, coach $(\alpha=0.81)$, protect $(\alpha=0.77)$, challenge $(\alpha=0.92)$ and exposure $(\alpha=0.80)$ that measures career function with 15 items; and friendship $(\alpha=0.82)$, social $(\alpha=0.93)$, parent $(\alpha=0.89)$, role model $(\alpha=0.84)$, counsel $(\alpha=0.83)$ and acceptance $(\alpha=0.89)$ that measures psychosocial function with 18 items.

Distributive justice was measured using a scale developed by Niehoff and Moorman (1993). The scale has 9 items measuring the fairness perceptions of employees. The Cronbach's alpha of the original scale is 0.91 . A sample item of the scale questions is "My work schedule is fair".

Organizational commitment was measured using a scale developed by Allen and Meyer (1990). The scale has 24 items under three dimensions; affective commitment (e.g. "I would be very happy to spend the rest of my career with this organization"), continuance commitment ("I don't consider leaving this organization because there are few other work options") and normative commitment ("This organization deserves my loyalty"). The Cronbach's alpha of the original subscales was $0.87,0.75$ and 0.79 , respectively.

Career satisfaction was measured using a scale developed by Greenhaus et al. (1990). The Career Satisfaction Scale has five items (e.g. "I am satisfied with the progress I have made regarding the accomplishment of my promotion objectives"). The Cronbach's alpha of the original scale was 0.88 .

\section{Results}

\subsection{Demographic Characteristics}

For study purposes, the study questionnaire was distributed to 300 participants; however, 20 questionnaires were ignored due to many missing parts, and all study analyses were conducted using the questionnaires of 280 participants. 
Table 1. Demographics

\begin{tabular}{|c|c|c|c|}
\hline & & $\mathrm{n}$ & $\%$ \\
\hline \multirow[t]{2}{*}{ Gender } & Single & 140 & $50.0 \%$ \\
\hline & Married & 140 & $50.0 \%$ \\
\hline \multirow[t]{5}{*}{ Age Group } & $=<20$ years & 11 & $3.9 \%$ \\
\hline & 21-30 years & 111 & $39.8 \%$ \\
\hline & $31-40$ & 84 & $30.1 \%$ \\
\hline & $41-50$ & 46 & $16.5 \%$ \\
\hline & $>=51$ years & 27 & $9.7 \%$ \\
\hline \multirow[t]{2}{*}{ Marital Status } & Single & 146 & $52.9 \%$ \\
\hline & Married & 130 & $47.1 \%$ \\
\hline \multirow[t]{4}{*}{ Education } & $\begin{array}{l}\text { Elementary } \\
\text { school }\end{array}$ & 8 & $2.9 \%$ \\
\hline & $\begin{array}{l}\text { Secondary-high } \\
\text { school }\end{array}$ & 60 & $21.4 \%$ \\
\hline & Bachelor & 141 & $50.4 \%$ \\
\hline & Graduate & 71 & $25.4 \%$ \\
\hline \multirow[t]{3}{*}{ Sector } & Service & 191 & $70.2 \%$ \\
\hline & Manufacturing & 37 & $13.6 \%$ \\
\hline & Commerce & 44 & $16.2 \%$ \\
\hline \multirow[t]{3}{*}{ Position/rank } & Top & 52 & $19.5 \%$ \\
\hline & Medium & 159 & $59.6 \%$ \\
\hline & Lower & 56 & $21.0 \%$ \\
\hline \multirow[t]{6}{*}{ Job_Seniority } & $<1$ year & 17 & $6.2 \%$ \\
\hline & $1-5$ years & 93 & $33.7 \%$ \\
\hline & $6-10$ years & 46 & $16.7 \%$ \\
\hline & $11-15$ years & 48 & $17.4 \%$ \\
\hline & $16-20$ years & 32 & $11.6 \%$ \\
\hline & $\geq 21$ years & 40 & $14.5 \%$ \\
\hline \multirow[t]{6}{*}{ Position_Seniorit } & $<1$ year & 39 & $14.9 \%$ \\
\hline & $1-5$ years & 140 & $53.6 \%$ \\
\hline & 6-10 years & 48 & $18.4 \%$ \\
\hline & $11-15$ years & 22 & $8.4 \%$ \\
\hline & $16-20$ years & 4 & $1.5 \%$ \\
\hline & $\geq 21$ years & 8 & $3.1 \%$ \\
\hline
\end{tabular}

\subsection{Statistical Analysis}

The responses of the participants were analyzed and interpreted using SPSS for Windows 22.00 and AMOS 22.0 software programs. Confirmatory factor analyses (CFA) of the research scales were performed and the Cronbach's alpha values were calculated. The confirmatory factor analysis of the research scales were conducted separately in the AMOS program. The path analysis of the structural equation model was performed using AMOS software program. 


\subsection{Confirmatory Factor Analysis}

Confirmatory factor analysis (CFA) was conducted to establish the significance of the measurement models in AMOS 22.0 software program. According to the results, the measurement models were acceptable. Then, goodness of fit index was used to assess the adequacy of the whole model.

With increasing sample size, especially in the samples greater than 200, the Chi-Square $\left(x^{2}\right)$ value gets higher and the statistical significance level of the Chi-Square (x2) test gets lower (Bollen, 1989; Fornell \& Larcker, 1981; Bagozzi et al., 1991). The confirmatory factor analysis of the study scales and the adequacy of the general models tested were assessed by using degree of freedom-adjusted Chi-Square $\left(x^{2}\right)$ value (Chi-Square value/degree of freedom), other goodness of fit indices and standardized residual covariance matrix values (Bayram, 2013).

Table 4. Standard Good Fit Indices and the Fit Indices Calculated for the Model

\begin{tabular}{llll}
\hline no & Fit Indices & Good Fit & Acceptable Fit \\
\hline 1 & $x^{2}$ & - & - \\
\hline 2 & $\mathrm{x}^{2} / \mathrm{s} \mathrm{d}$ & $\mathbf{0}<\mathrm{x}^{2} / \mathrm{d} \mathrm{f}<\mathbf{2}$ & $2<\mathrm{x}^{2} / \mathrm{s} \mathrm{d}<5$ \\
\hline 3 & RMSEA & $0<\mathrm{RMSEA}<0.05$ & $0.05<\mathrm{RMSEA}<0.08$ \\
\hline 4 & GFI & $0.95<\mathrm{GFI}<1.00$ & $0.90<\mathrm{GFI}<0.95$ \\
\hline 5 & CFI & $0.97<\mathrm{CFI}<1.00$ & $0.95<\mathrm{CFI}<0.97$ \\
\hline 6 & SRMR & $0<\mathrm{SRMR}<0.05$ & $0.05<\mathrm{SRMR}<0.10$ \\
\hline
\end{tabular}

\subsubsection{Organizational Commitment (OC) Scale}

The organizational commitment scale consists of 18 items and 3 subdimensions. Due to their factor loads $(<0.50), 9$ items of the scale were removed from the analysis. Confirmatory factor analysis was performed using the remaining 9 items and 3 subdimensions.

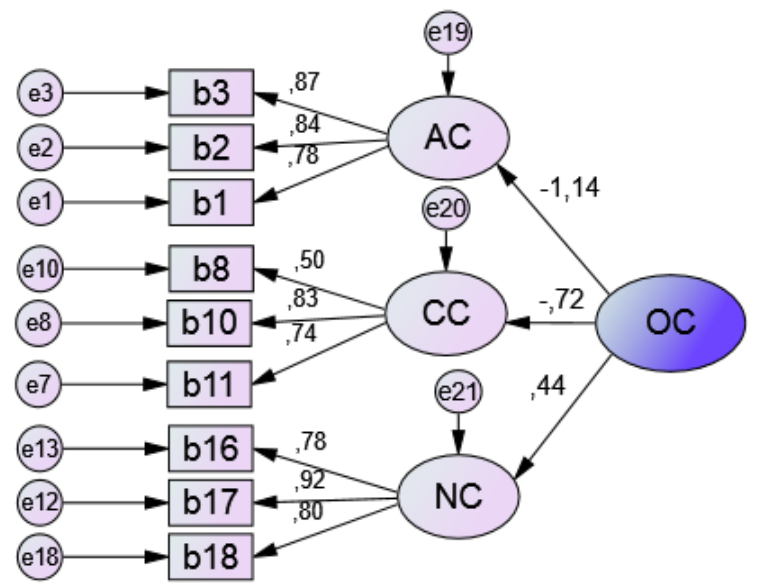

Figure 1. The OC Scale-Confirmatory Factor Analysis

The model was within the acceptable limits as the result of the model analysis was $x^{2} / \mathrm{df}(1.594)$. The goodness of fit indices of the model were found as RMSEA $=0.046$, GFI $=0.971, \mathrm{CFI}=0.989$ and $\mathrm{SRMR}=0.0376$. Based on these values, the research model is considered to be within the acceptable limits.

\subsubsection{Carrier Satisfaction (CR) Scale}

The career satisfaction scale consists of 5 items and a single subdimension. No item was removed from the analysis as the factor loads of all items were $(>0.50)$. The confirmatory factor analysis performed using 5 items a single subdimension is provided below. 


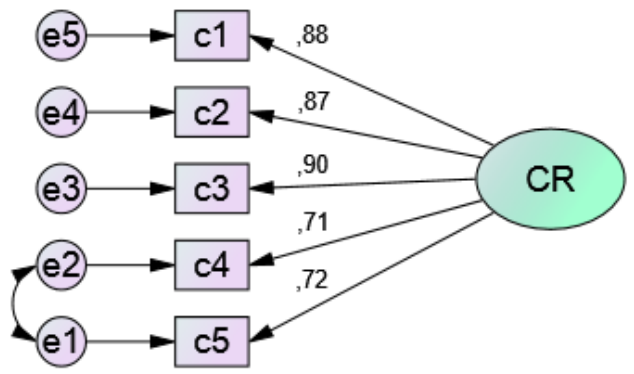

Figure 2. The CR Scale-Confirmatory Factor Analysis

The model was within the acceptable limits as the result of the model analysis was $x^{2} / \mathrm{df}(1.073)$. The goodness of fit indices of the model were found as RMSEA $=0.016, \mathrm{GFI}=0.995, \mathrm{CFI}=0.998$ and $\mathrm{SRMR}=0.0090$. Based on these values, the research model is considered to be within the acceptable limits.

\subsubsection{Distributive Justice (DJ)}

The distributive justice scale consists of 5 items and a single subdimension. No item was removed from the analysis as the factor loads of all items were ( $>0.50)$. The confirmatory factor analysis performed by using 5 items and a single subdimension is provided below.

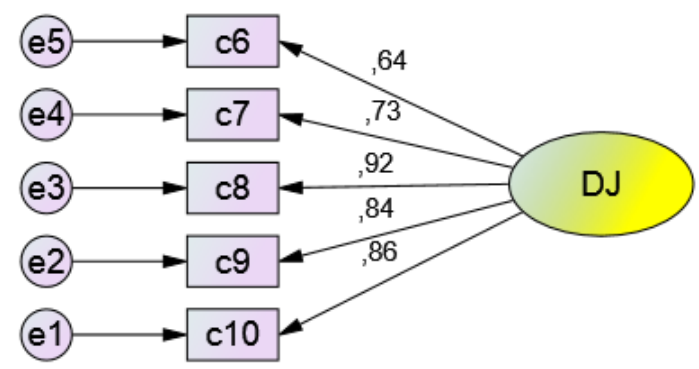

Figure 3. The DJ Scale-Confirmatory Factor Analysis

The model was within the acceptable limits as the result of the model analysis was $x^{2} / \mathrm{df}(1.011)$. The goodness of fit indices of the model were found as RMSEA $=0.006, \mathrm{GFI}=0.997, \mathrm{CFI}=0.999$ and $\mathrm{SRMR}=0.0077$. Based on these values, the research model is considered to be within the acceptable limits.

7.3.4 Mentor Role Instrument (MRI)

The mentor role instrument consists of 33 items and 11 subdimensions. In the study, 18 items and 6 subdimensions that were related to the research model were used. Therefore, the confirmatory factor analysis was performed using 18 items and 6 subdimensions. An item (Item 7) with a factor load of $(<0.50)$ was removed from the analysis. The result of the confirmatory factor analysis performed by using the remaining 17 items is as follows: 


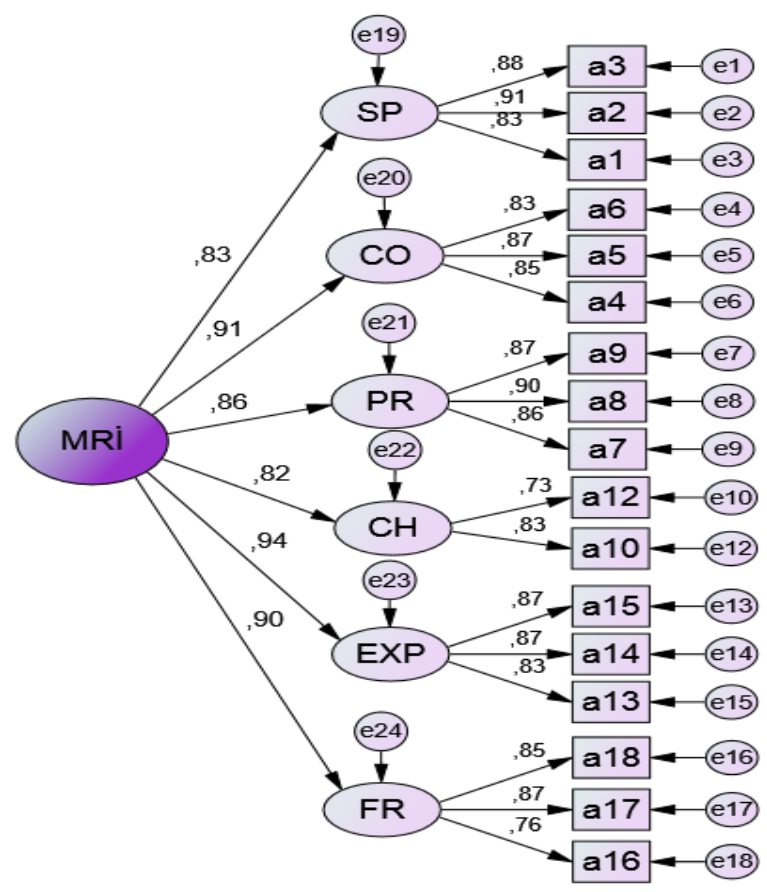

Figure 4. MRI - Confirmatory Factor Analysis

The model was within the acceptable limits as the result of the model analysis was $x^{2} / \mathrm{df}(2.128)$. The goodness of fit indices of the model were found as RMSEA $=0.064$, GFI $=0.910, \mathrm{CFI}=0.967$ and $\mathrm{SRMR}=0.0345$. Based on these values, the research model is considered to be within the acceptable limits.

\subsection{Path Analysis of the Structural Equation Model}

A path diagram was drawn using AMOS 22.0 software program to examine the relationships assumed in the hypotheses, and the structural parameters were estimated using the Maximum Likelihood method. The path diagram of the model is presented in Figure 6. The AMOS SEM program provides analysis results as standardized and non-standardized coefficients separately. Standardized coefficients were utilized in the analysis for understandability.

Since the chi-square value calculated for the fitness of the model in the structural equation modeling may lead to incorrect decisions as it is affected by the sample size and the number of variables, the decision is made based on the (x2/ df.) criterion instead of this value (Jöreskog \& Sörbom, 1996; Schermelleh-Engel et.al., 2003). 


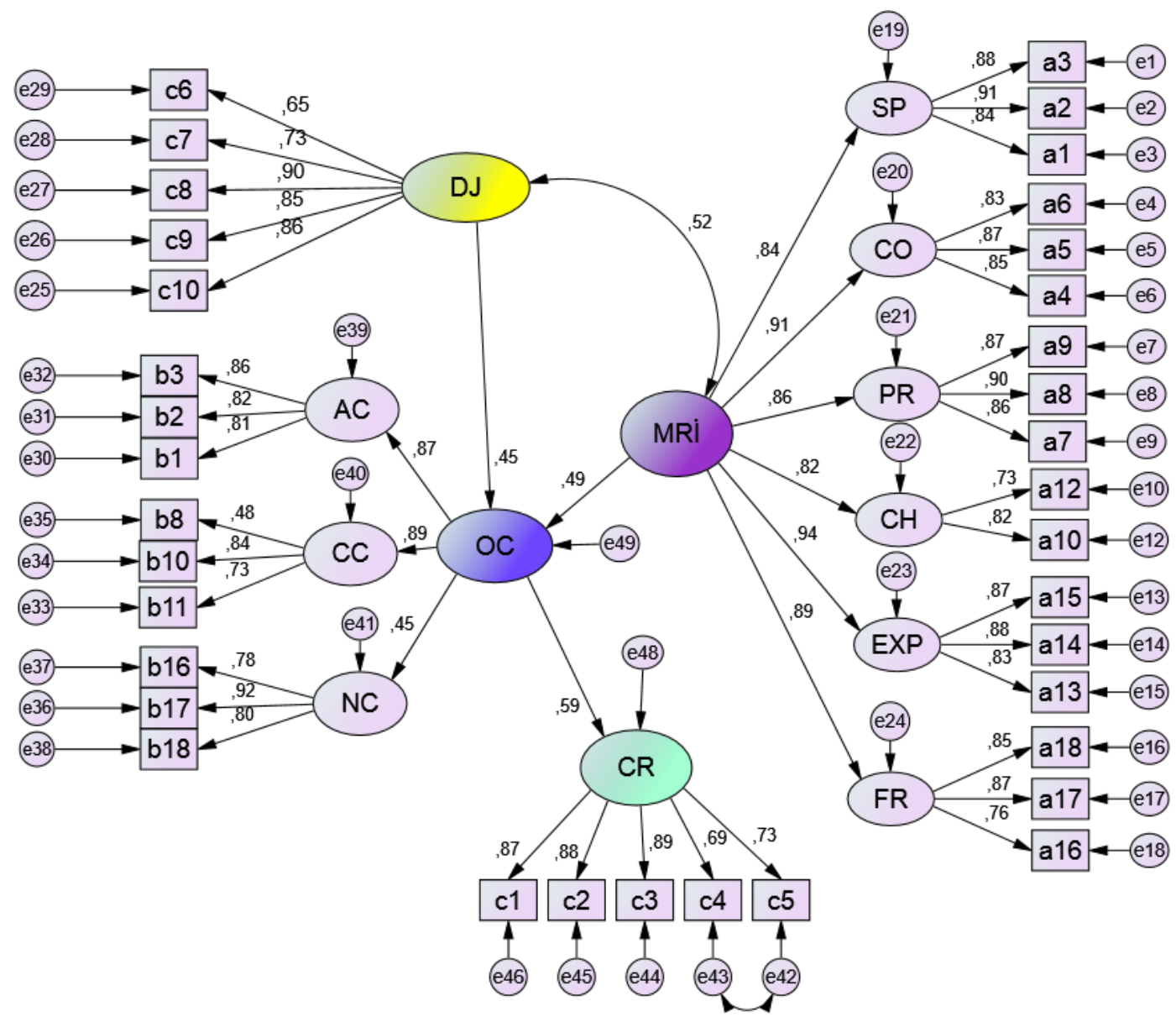

Figure 5. Path analysis of the presumed model using structural equation modeling

Table 2. Standard Good Fit Indices and the Fit Indices Calculated for the Model

\begin{tabular}{lllll}
\hline no & Fit Indices & Good Fit & Acceptable Fit & Model \\
\hline 1 & $x^{2}$ & - & - & 1.177595 \\
\hline 2 & $\mathrm{x}^{2} / \mathrm{s} \mathrm{d}$ & $\mathbf{0}<\mathrm{x}^{2} / \mathrm{d} \mathrm{f}<\mathbf{2}$ & $2<\mathrm{x}^{2} / \mathrm{s} \mathrm{d}<3$ & 2048 \\
\hline 3 & RMSEA & $0<\mathrm{RMSEA}<0.05$ & $0.05<\mathrm{RMSEA}<0.08$ & 0061 \\
\hline 4 & GFI & $0.95<\mathrm{GFI}<1.00$ & $0.90<\mathrm{GFI}<0.95$ & 0903 \\
\hline 5 & CFI & $0.97<\mathrm{AGFI}<1.00$ & $0.95<\mathrm{AGFI}<0.97$ & $\mathbf{0 9 5 1}$ \\
\hline 6 & SRMR & $0<\mathrm{SRMR}<0.05$ & $0.05<\mathrm{SRMR}<0.10$ & 0066
\end{tabular}

The model was statistically significant as $x^{2} / \mathrm{df}=2.048$. This value is within the "acceptable fit" limits. RMSEA was 0.061 , GFI was 0.903 , CFI was 0.951 and SRMR was 0.066 . Fit indices related to the model fit are presented in Table 4. These values indicate that the research model is within the acceptable limits.

The model revealed that distributive justice and mentor role affect organizational commitment, whereas organizational commitment has an effect on career satisfaction. Additionally, the covariance between distributional justice and mentor role was statistically significant. The findings from the model are shown in Table 3. 
Table 3. Regression and determination coefficients

\begin{tabular}{|c|c|c|c|c|c|c|}
\hline $\begin{array}{l}\text { Endogen } \\
\text { ous }\end{array}$ & $\begin{array}{l}\text { Effec } \\
t\end{array}$ & Exogenous & $\begin{array}{l}\text { Non-standardized (?) } \\
\text { coefficients }\end{array}$ & $\begin{array}{l}\text { Non-standardized } \\
\text { coefficients }\end{array}$ & $\mathbf{z}$ & $\mathbf{p}$ \\
\hline $\mathrm{OC}$ & $<---$ & DJ & .246 & .454 & 5344 & $* * *$ \\
\hline $\mathrm{OC}$ & $<---$ & MRİ & .284 & .485 & 5374 & $* * *$ \\
\hline $\mathrm{CR}$ & $\begin{array}{l}<-- \\
\end{array}$ & OC & .857 & .591 & 5663 & $* * *$ \\
\hline \multicolumn{5}{|c|}{ Structural Equations } & \multicolumn{2}{|c|}{$\mathbf{R}^{2}$} \\
\hline \multicolumn{5}{|c|}{$\mathbf{O C}=0.454 * \mathrm{DJ}+0.485 * \mathrm{MRI}$} & \multicolumn{2}{|c|}{$67 \%$} \\
\hline \multicolumn{5}{|c|}{$\mathbf{C R}=0.591 * \mathrm{OC}$} & \multicolumn{2}{|c|}{$35 \%$} \\
\hline
\end{tabular}

Organizational commitment is positively affected by mentor role and distributive justice. Organizational commitment was explained by these variables at a rate of $35 \%$. Career satisfaction is positively affected by organizational commitment. Career satisfaction was explained by these variables at a rate of $67 \%$. Besides, the relationship (covariance) between mentor role and distributive justice was found to be positive (0.52) and significant.

\section{Conclusion and Implications}

The present research tried to establish the relationships among four variables; mentoring, distributive justice, organizational commitment and career satisfaction. We believe that the research findings will contribute to the existing literature on these constructs as well as provide organizations with substantial information on how to enhance organizational commitment among their members to achieve better organizational outcomes.

Our findings have first demonstrated that mentoring has a positive relationship with distributive justice. This finding may expand our understanding of both mentoring and employee perceptions of justice. As commitment is a very valuable concept for organizations, particularly for employee effectiveness and retention, organizations may pay further attention to the characteristics of their mentoring program and employees' fairness perceptions in order to enhance their commitment to the organization. Distributive justice is about employees' perceptions of fairness in reward allocation; therefore, organizations should diligently formulate mentoring programs considering fair access of all employees due to such interaction. Furthermore, this finding suggests that employees believe their organization is fair when they perceive their mentor as fair. In this regard, organizations may train their experienced employees to serve as mentors about fair treatment and employee perceptions. The function of mentoring, which contributes more to the justice perceptions, may be investigated by future studies.

Second, we have determined that mentoring positively influences employees' organizational commitment. This finding is consistent with the literature (e.g. Allen \& Meyer, 1990; McManus \& Russell, 1997). Based on this, we recommend organizations to provide their members, especially newcomers, with an effective mentoring program. The mentoring process can help building long-term relationships between an organization and its members. Thereby, employees would feel more committed to their employing organization and not develop any intent to leave. Accordingly, mentoring is likely to provide employee retention, which may be an area of research for future studies.

Third, we have found that organizational commitment is positively affected by distributive justice. This finding is consistent with the studies by Aryee et al. (2002) and Lambert et al. (2007). This suggests that there should be a good management of justice in organizations as justice perceptions are likely to determine job outcomes. Therefore, we recommend organizations to be just and fair with their employees in all their practices in order to have committed members. Organizations may also develop management strategies that will foster fairness through any method such as monthly meetings or open-door policies, whichever is practical for them.

Fourth, our results have revealed that organizational commitment is related to career satisfaction. This finding is consistent with the studies by Carson et al. (1996), and Hsu and Tsuai (2014). As an important indicator of career success, career satisfaction should not be ignored by organizations. This finding suggests that employees who feel more committed to their organization are more satisfied with their career, which is likely to result in a successful career. In this sense, organizations may provide their employees with training to enhance their professional skills and make efforts to meet their physical and mental needs.

In conclusion, considering all of our findings, it is possible to state that an organization is likely to have committed employees when it executes a mentoring program and supports an equal and just working environment, which then results in employees satisfied with their career. 


\section{References}

Adams, J.S. (1965). Inequity in social exchange. Advances in Experimental Social Psychology, 2, $267-299$. https://doi.org/10.1016/S0065-2601(08)60108-2

Akanbi, P.A., \& Ofoegbu, O.E. (2013). Impact of perceived organizational justice on organizational commitment of a food and beverage firm in Nigeria. International Journal of Humanities and Social Sciences, 3(14), $207-218$.

Allen, N.J., \& Meyer, J.P. (1990). The measurement and antecedents of affective, continuance, and normative commitment to the organization. Journal of Occupational Psychology, 63, 1-18. https://doi.org/10.1111/j.2044-8325.1990.tb00506.x

Allen, T.D., Eby, L.T., Poteet, M.L., Lentz, E., \& Lima, L. (2004). Career benefits associated with mentoring for proteges: A meta-analysis. Journal of. Applied Psychology, 89(1), 127. https://doi.org/10.1037/0021-9010.89.1.127

Allen, T.D., Poteet, M.L., Russell, J.E.A., \& Dobbins, G.H. (1997). A field study of factors related to willingness to mentor others. Journal of Vocational Behavior, 50, 1-22. https://doi.org/10.1006/jvbe.1995.1525

Aryee, S., Budhwar, P.S., \& Chen, Z.C. (2002). Trust as a mediator of the relationship between organizational justic and work outcomes: test of a social exchange model. Journal of Organizational Behavior, 23, $267-285$. https://doi.org/10.1002/job.138

Ashar, M., \& Shahbaz, W. (2013). Impact of organizational justice and supportive management on employees' customer oriented behavior in service sector of Pakistan. 3rd International conference on Business Management (pp. 1-18). Lahore.

Atkinson, W. (2002). Mentoring programs pick up where training leaves off. Purchasing, 131(2), $18-19$.

Bagozzi, R.P., Yi, Y., \& Phillips, L.W. (1991). Assessing Construct Validity in Organizational Research. Administrative Science Quarterly, 36(3), 421-58. https://doi.org/10.2307/2393203

Bayram, N. (2013). Yapısal eşitlik modellemesine giriş: Amos uygulamaları. Ezgi Yayınevi.

Bollen, K.A. (1989). Structural equations with latent variables. New York: Wiley. https://doi.org/10.1002/9781118619179

Bozeman, B., \& Feeney, M.K. (2007). Toward a useful theory of mentoring: A conceptual analysis and critique. Administration \& Society, 39, 719-739. https://doi.org/10.1177/0095399707304119

Carson, K.D., Carson, P.P., Phillips, J.S., \& Roe, C.W. (1996). A career entrenchment model: Theoretical development and empirical outcomes. Journal of Career Development, 22(4), 273-286. https://doi.org/10.1007/BF02259996

Chang, C., \& Dubinsky, A.J. (2005). Organizational Justice in Sales Force: A Literature Review with Propositions. Journal of Business to Business Marketing, 12(1), 35-71. https://doi.org/10.1300/J033v12n01_03

Colarelli, S.M., \& Bishop, R.C. (1990). Career commitment: functions, correlates and management. Group \& Organizational Studies, 15, 158-76. https://doi.org/10.1177/105960119001500203

Crant, J.M. (2000). Proactive behavior in organizations. Journal of Management, 26(3), 435-462. https://doi.org/10.1177/014920630002600304

Cropanzano, R., Byrne, Z.S., Bobocel, D.R., \& Rupp, D.R. (2001). Moral virtues, fairness heuristics, social entities, and other denizens of organizational justice. Journal of Vocational Behavior, 58, 164-209. https://doi.org/10.1006/jvbe.2001.1791

Darling, N., Bogat, G.A., Cavell, T.A., Murphy, S.E., \& Sanchez, B. (2006). Gender, ethnicity, development, and risk: mentoring and the consideration of individual differences. Journal of Community Psychology, 34(6), 765-779. https://doi.org/10.1002/jcop.20128

Eby, L.T., McManus, S.E., Simon, S.A., \& Russell, J.E. (2000). The protégé's perspective regarding negative mentoring experiences: the development of a taxonomy. Journal of Vocational Behavior, 57, 1-21. https://doi.org/10.1006/jvbe.1999.1726

Ensher, E.A., Thomas, C., \& Murphy, S.E. (2001). Comparison of traditional, step-ahead, and peer mentoring on protégés support, satisfaction, and perceptions of career success: a social exchange perspective. J. Bus. Psychol. 15, 419-438. https://doi.org/10.1023/A:1007870600459

Fernandes, C., \& Raed, A. (2006). Impact of organizational justice in an expatriate work environment. Management Research News, 29(11), 701-712. https://doi.org/10.1108/01409170610716016 
Fine, L.M., \& Pullins, E.B. (1998). Peer mentoring in the industrial sales force: An exploratory investigation of men and women in developmental relationships. Journal of Personal Selling \& Sales Management, 18, 89-103.

Fornell, C., \& Larcker, D.F. (1981). Evaluating structural equation models with unobservable variables and measurement error. Journal of Marketing Research, 18(1), 39-50. https://doi.org/10.2307/3151312

Greenberg, J., \& Baron, R.A. (2003). Behavior in organizations: Understanding and managing the human side of work $\left(8^{\text {th }}\right.$ Ed. $)$. New Jersey: Prentice Hall.

Greenhaus, J.H., Parasuraman, S., \& Wormley, W.M. (1990). Effects of race on organizational experiences, job performance evaluations, and career outcomes. Academy of Management Journal, 33(1), 64-86. https://doi.org/10.2307/256352

Haggard, D.L., Dougherty, T.W., Turban, D.B., \& Wilbanks, J.E. (2011). Who is a mentor? A review of evolving definitions and implications for research. Journal of Management, 37(1), 280-304. https://doi.org/10.1177/0149206310386227

Higgins, M., \& Kram, K. (2001). Reconceptualizing Mentoring at Work: A Developmental Network Perspective. Academy of Management Review, 26, 264-288. https://doi.org/10.5465/AMR.2001.4378023

Hofmans, J., Dries, N., \& Pepermans, R. (2008). The career satisfaction scale: Response bias among men and women. Journal of Vocational Behavior, 73, 397-403. https://doi.org/10.1016/j.jvb.2008.08.001

Hsu, M.S., \& Tsai, Y.Y. (2014). Career satisfaction and organizational commitment among hotel employees in Taiwan. Journal of Hotel \& Business Management, 3, 107.

Jaskyte, K., \& Lee, M. (2009). Organizational Commitment of Social Workers: An Exploratory Study. Administration in Social Work, 33(1), 227-241. https://doi.org/10.1080/03643100902987283

Joo, B.K., \& Ready, K.J. (2012). Career satisfaction: The influences of proactive personality, performance goal orientation, organizational learning culture, and leader-member exchange quality. Career Development International, 17(3), 276-295. https://doi.org/10.1108/13620431211241090

Jöreskog , K.G., \& Sorbom, D. (2003). LISREL 8.54 for Windows [Computer Software]. Lincolnwood, IL: Scientific Software International.

Judge, T.A., Cable, D.M., Boudreau, J.W., \& Bretz, R.D. (1995). An empirical investigation of the predictors of $\begin{array}{lllll}\text { executive career } \quad \text { success. } & \text { Personnel } & \text { Psychology, } & 48, & \text { 485-519. }\end{array}$ https://doi.org/10.1111/j.1744-6570.1995.tb01767.x

Judge, T.A., \& Kammeyer-Mueller, J.D. (2007). Personality and career success. In M. Peiperl \& H. Gunz (Eds.), Handbook of Career Studies, (pp. 59-78). Thousand Oaks, CA: Sage. https://doi.org/10.4135/9781412976107.n4

Kram, K.E. (1985). Mentoring at Work: Developmental Relationships in Organizational Life. New York: Scott, Foresman and Company.

Lambert, E.G., Hogan, N.L., \& Griffin, M.L. (2007). The impact of distributive and procedural justice on correctional staff job stress, job satisfaction, and organizational commitment. Journal of Criminal Justice, 35, 644-656. https://doi.org/10.1016/j.jcrimjus.2007.09.001

Lankau, M.J., \& Scandura, T.A. (2002). An investigation of personal learning in mentoring relationships: content, antecedents and consequences. Academy of Management Journal, 45, 779-790. https://doi.org/10.2307/3069311

Lee, S.H., Lee, T.W., \& dan Lum, C.F. (2007). The effects of employee services on organizational commitment and intentions to quit. Personnel Review, 37(2), 222-237. https://doi.org/10.1108/00483480810850551

Loi, R., Hang-yue, N., \& Foley, S. (2006). Linking employees' justice perceptions to organizational commitment and intention to leave: The mediating role of perceived organizational support. Journal of Occupational and Organizational Psychology, 79(1), 101-120. https://doi.org/10.1348/096317905X39657

Lounsbury, J.W., Steel, R.P., Gibson, L.W., \& Drost, A.W. (2008). Personal traits and career satisfaction of human resource professionals. Retrieved from http://info.ecareerfit.com/eCareerFit/CareerSatisfaction_HRProfessionals_final2.pdf

McManus, S.E., \& Russell, J.E.A. (1997). New directions for mentoring research: an examination of related constructs. Journal of Vocational Behavior, 51, 145-61. https://doi.org/10.1006/jvbe.1997.1597 
Moorman, R.H. (1991). Relationship between organizational justice and organizational citizenship behavior: Do fairness perceptions influence employee Citizenship? Journal of Applied Psychology, 76, 845-855. https://doi.org/10.1037/0021-9010.76.6.845

Murphy, W.M. (2012). Reverse mentoring at work: fostering cross-generational learning and developing millennial leaders. Human Resource Management, 51(4), 549-574. https://doi.org/10.1002/hrm.21489

Niehoff, B.P., \& Moorman, R.H. (1993). Justice as a mediator of the relationship between methods of monitoring and organizational citizenship behavior. Academy of Management Journal, 36, 527-556. https://doi.org/10.2307/256591

O_Reilly, D. (2001). The mentoring of employees: Is your organization taking advantage of this professional development tool? Ohio CPA Journal, 60(3), 51-54.

Orpen, C. (1997). The effects of formal mentoring on employee work motivation, organizational commitment and job performance. The Learning Organization, 4(2), 53 - 60. https://doi.org/10.1108/09696479710160906

Özkalp, E., Kırel, C., Sungur, Z., \& Cengiz, A.A. (2006). Mentoring Revisited from the Perspective of Mentors in Learning Process: The Case of Anadolu University in Turkey. 7. International Conference on Human Resource Development, Tilburg University, Holland.

Park, Y. (2010). The predictors of subjective career success: An empirical study of employee development in a Korean financial company. International Journal of Training and Development, 14(1), 4. https://doi.org/10.1111/j.1468-2419.2009.00337.x

Ragins, B.R., \& Kram, K.E. (2007). The handbook of mentoring at work theory, research, and practice. Los Angeles: Sage Publications, Inc.

Ragins, B.R., \& McFarlin, D. (1990). Perception of mentor roles in cross-gender mentoring relationships. Journal of Vocational Behavior, 37, 321-339. https://doi.org/10.1016/0001-8791(90)90048-7

Ragins, B.R., \& Verbos, A.K. (2007). Positive relationships in action: relational mentoring and mentoring schemas in the workplace. In J.E. Dutton, \& B.R. Ragins (Eds.), Exploring positive relationships at work: building a theoretical and research foundation (pp. 91-116). Mahwah, NJ: Lawrence Erlbaum.

Ragins, B.R., Cotton, J.L., \& Miller, J.S. (2000). Marginal mentoring: the effects of type of mentor, quality of relationship, and program design on work and career attitudes. Academy of Management Journal, 43, 1177-1194. https://doi.org/10.2307/1556344

Ramamoorthy, N., \& Flood, P.C. (2004). Gender and employee attitudes: The role of organizational justice perceptions. British Journal of Management, 15, 247-258. https://doi.org/10.1111/j.1467-8551.2004.00417.x

Reid, M.F., Allen, M.W., Riemenschneider, C.K., \& Armstrong, D.J. (2008). The role of mentoring and supervisor for state IT employees' affective organizational commitment. Review of Public Personnel Administration, 28(1), 60-78. https://doi.org/10.1177/0734371X07311703

Scandura, T.A. (1992). Mentorship and career mobility: An empirical investigation. Journal of Organizational Behavior, 13, 169-174. https://doi.org/10.1002/job.4030130206

Scandura, T.A. (1997). Mentoring and organizational justice: An empirical investigation. Journal of Vocational Behavior, 51, 58-69. https://doi.org/10.1006/jvbe.1997.1588

Schermelleh-Engel, K., Moosbrugger, H., \& Müller, H. (2003). Evaluating the fit of structural equation models. Methods of Psychological Research, 8(2), 23-74.

Seibert, S.E., \& Kraimer, M.L. (2001). The fivefactor model of personality and career success. Journal of Vocational Behavior, 58, 1-21. https://doi.org/10.1006/jvbe.2000.1757

Thomas, D.A. (1993). Racial dynamics in cross-race developmental relationships. Administrative Science Quarterly, 38, 169-94. https://doi.org/10.2307/2393410

Viator, R.E. (2001). The association of formal and informal public accounting mentoring with rolestress and related job outcomes. Accounting, Organizations and Society, 26, 73-93. https://doi.org/10.1016/S0361-3682(00)00002-7

Weinberg, F.J., \& Lankau, M.J. (2011). Formal mentoring programs: A mentorcentric and longitudinal analysis. Journal of Management, 37(6), 1527-1557. https://doi.org/10.1177/0149206309349310 